UDC: $615.456 .1: 615.014 .83: 619$

DOI: $10.15587 / 2519-4852.2018 .124449$

\title{
STUDY OF INFLUENCE OF PRIMARY PACKAGING ON THE STABILITY OF THE ORIGINAL VETERINARY PREPARATION
}

\author{
(C) Z. Polova, L. Almakayeva
}

Важливе значення при створенні ветеринарних препаратів надається вибору первинної упаковки, мате-
ріал якої безпосередньо контактує з лікарською формою. Стабільність зразків ветеринарних препара-
тів необхідно досліджувати в упаковках, які будуть застосовувати під час серійного виробництва ліків.
Також необхідно дослідти процеси, які можуть відбуватися з активними фармацевтичними інгредіє-
нтами під впливом речовин, щчо містяться в пакувальному матеріалі. На основі цих даних встановлю-
ють терміни придатності препарату у відповідній упаковці. Мета. Дослідження впливу первинної упаковки на показники якості розчину на основі цчитрату срібла під умовною назвою «Аргоиид», а саме: ампул ємністю 10 мл та флаконів ємністю 50 мл скляних світлозахисних; пластмасових контейнерах (ампулах) ємністю 10 мл та флаконів ємністю 50 мл.

Методи. Методи досліджень проводили згідно з вимогами Державної Фармакопеї України.

Результати дослідження. Досліджено, щзо пластмасові контейнери місткістю 10 мл з поліетилену марки Pharmalene ${ }^{\circledR}$, флакони по 50 мл з поліетилену низької щільності марки Riblene ${ }^{\circledR}$ FL 20 PH, не викликають змін показників якості ветеринарного розчину, регламентованих в специфікаиї та дозволяють зберігати препарат стабільним протягом терміну зберігання 2 роки. В процесі зберігання розчину на основі срібла цитрату у пластмасових контейнерах з поліетилену марки Pharmalene ${ }^{\circledR}$ місткістю 10 мл протягом 2 років відбулося зменшення об'єму до 1,5\%. Однак, швидкість випаровування розчинника занадто мала для того, щзоб концентрація діючих речовин вийшла за допустимі значення.

Висновки. Встановлено, щзо всі досліджувані види контейнерів придатні для застосування в якості первинного пакування для ветеринарного препарату «Аргочиид, розчину для інтрачистернального введення на основі ичитрату срібла, оскільки дозволяють зберігати препарат стабільним протягом 2-х років

Ключові слова: ветеринарний препарат, первинне пакування, стабільність, цитрат срібла

\section{Introduction}

At the present stage of the development of the pharmaceutical production of veterinary preparations, the issue of packaging medicinal products is urgent. Requirements for packing are contained in the relevant sections of the State Pharmacopoeia of Ukraine (SPhu), the instructions of the ST-N MHU 42-3.16: 2014 "LZ. Plastic materials for primary packaging of medicinal products ", as well as in international pharmacopoeias and ISO standards [1].

The principle of selecting the packaging materials is common to all pharmaceutical forms in pharmaceutical practice. Particular importance when creating the medicinal product is given to the choice of primary packaging, whose material is directly in contact with the dosage form. The choice of a particular type of primary packaging should be based on studies on the compatibility of the medicinal composition with the material of the package itself. The packaging for the medicinal product must guarantee its quality during transport and storage throughout its shelf-life. The most advanced stabilization methods will be ineffective if you do not take into account the chemical composition and properties of the packaging materials, with which the components of the veterinary drug are in direct contact with the time of their preparation for use [2].

In connection with the transfer of veterinary preparations for compliance with the requirements of GMP there is a number of specific conditions that need to be considered when choosing the primary packaging. One of the basic and fundamental requirements of GMP is the maximum reproducibility and repeatability of processes, as well as minimal participation in these processes of a person. This means that all processes for the production of veterinary preparations should be automated, with all the packaging elements to be standardized, without deviations from the given sizes, processed on automatic lines [3, 4].

2. Formulation of the problem in a general way, the relevance of the theme and its connection with important scientific and practical issues $и$

One of the factors that ensure the stability of the drug during storage is the material of the primary packaging. To confirm the compatibility of the container and its contents, to make sure that no changes affecting the quality of the drug occur in a variety of tests at the stage of pharmaceutical design. This is, first of all, a check of the absence of changes in the physical characteristics of the medicinal product, the determination of $\mathrm{pH}$ changes; evaluation of changes caused by the action of light; chemical tests; biological tests. When using plastic containers, any losses or increment of material permeability should be evaluated [5].

The design of the primary packaging should ensure: protection of the drug from the effects of adverse effects of the environment; to protect against mechanical influences; to provide tightness, to protect against microbial contamination; to provide a dosage extract of the drug; have aesthetic appearance and be comfortable to use; structural elements must be standardized, there must be no deviations from the geometric dimensions. The primary packaging must be made of materials that have been examined and registered by the relevant authorities of Ukraine and comply with the requirements of the SPF. 
Also materials should not contain: heavy metals, arsenic, other harmful impurities, in quantities exceeding the standards; dyes not allowed to use; carcinogenic and toxic components $[6,7]$.

The stability of the veterinary drug depends largely on the chemical composition and properties of the packaging material. In the case of the study of the possibility of using one or another material necessary preliminary physical, chemical and biological tests. Not only the stability of the packaging material, but also its ability to protect the drug from the influence of temperature, light, and humidity is important. Therefore, the stability of samples of veterinary medicines should be investigated in packages that will be used during serial production of drugs. It is also necessary to investigate the processes that can occur with active pharmaceutical ingredients under the influence of substances contained in the packaging material. On the basis of these data, determine the shelf life of the drug in the appropriate package.

\section{Analysis of recent studies and publications in which a solution of the problem are described and to which the author refers}

At the stage of pharmaceutical development of a medicinal product, the study of stability in primary packaging is a prerequisite. Such studies are conducted by the authors of the development for all dosage forms. Processes occurring during storage may lead to changes in the physicochemical properties of the medicinal product. In the first stages of the research, stress tests are conducted that provide an opportunity to justify the choice of composition, technology and primary packaging. Accelerated trials are used to predict the shelf life, and the long-term stability tests of the drug are the most promising ones.

The primary packaging for sterile veterinary drugs is traditionally glass vials or vials. Since the choice of packaging should be substantiated at the stage of pharmaceutical development, for glass packaging it is necessary to pay attention to the characteristic processes of interaction between the glass and the individual components of the preparation and for stoppers - the processes of sorption, desorption or diffusion of substances in the solution [8]. However, at the same time, the fragility of glass is a serious disadvantage, so a secondary road packaging is needed to prevent the broken ampules, depressurization of ampules, splitting. During the storage of some veterinary medicines, direct sunlight is not allowed, therefore the package should be opaque or, for example, glass bottles made of brown glass $[9,10]$.

Currently, plastic containers are increasingly being used in connection with the development of the market for veterinary medicines. The Blow-Fill-Sill technology, recognized in the world as the most advanced for the production of sterile medicinal solutions, allows the production of sterile solutions in polyethylene ampoules or vials [11]. With such a technology, the formation, filling and sealing of the ampule during production is one cycle. Plastic containers have a number of advantages over traditional glass packaging. They are comfortable and safe to use, easy to open when turning the head of the ampoule. The entire cycle of preparation of the primary packaging that is present in the preparation of glass vials and vials is excluded $[12,13]$.

The light transmission capacity of plastic containers is lower than ones of glass, which makes it possible to use them as primary packaging for drugs that need to be protected from light, but on the other hand it affects the impossibility of direct visual control as one of the indicators for mechanical inclusion. The advantage of this packaging is that the sterility of the plastic is achieved by extruding at a temperature from $1700 \mathrm{C}$ to $2300 \mathrm{C}$. The molten granules of polyethylene are pressed into a sterile plastic tube and blown into a container of a given design. The container is then filled with sterile filtered solution and sealed by welding the container head (ampoule) [14].

The disadvantages of plastic containers used as primary packaging of veterinary medicines are permeability for vapour and gases, and consequently, a decrease in content and a change in the quantitative content of substances in the preparation; the ability to adsorb components of the contents of the package [15].

\section{The field of research considering the general problem, which is described in the article}

This work is a continuation of experimental research on theoretical and experimental substantiation of the composition and technology of drugs of antimicrobial action for use in veterinary medicine (within the framework of the research work of the Department of Management and Economics of Pharmacy with Technology of Ternopil State Medical University named after I. Y. Gorbachevsky on the subject : "Marketing, pharmacoeconomic and technological research on the development of medicinal products" (state registration number 0115U001530) [16, 17].

For such a direction of scientific research, such as studying and choosing the primary packaging of sterile veterinary medicines, the information is generally informative, and for the particular drugs is virtually absent. This may be due to various reasons, one of which is that these data are contained in the dossier for the drug and are practically not published.

Research on the selection of primary packaging for a sterile solution for intramammary use on the basis of silver citrate was conducted for the first time. The results obtained in the complex of works are necessary for recommendations on the choice of the primary packaging for manufacturers of the finished medicinal product, the development of normative documentation for production and control.

\section{Formulation of goals (tasks) of article}

The aim of the experiment is to study the influence of primary packaging on the quality of the solution based on silver citrate under the conventional name "Argocid" - a combined aqueous solution consisting of three active substances (silver citrate, dexpanthenol and arginine) and auxiliary substances to determine the shelf life of the veterinary drug in the appropriate packaging.

6. Presentation of the main research material (methods and objects) with the justification of the results

The research was carried out under the conditions of the research laboratory of parenteral and oral liquid medicinal products at the National Pharmaceutical Uni- 
versity (Kharkiv, Ukraine) and at the research site on the production of sterile veterinary drugs at the TOV "Brovafarma" (Brovary, Ukraine).

According to the literature, the stability of silver citrate depends on the $\mathrm{pH}$ of the medium, temperature, the action of oxygen in the air, and light. Storage of the silver citrate solution should be in a non-transparent container away from sunlight. In the model mixtures of citrate solution of silver, dexpanthenol, arginine, which were exposed to light, there was a change in the transparency of the drug. These facts were taken into account during choosing the primary packaging for the ready dosage form.

We investigated as primary packaging: lightprotective ampoules IP-10B KI-sz according to TU 00480945-005-96 from neutral light protection glass 1 of the hydrolytic class Fiolax-cz (production of OJSC Poltava Medical Glass Factory; $50 \mathrm{ml}$ bottles of lightprotective glass (production of the company "Shandong Pharmaceutical Glass Co., Ltd", China) from sodium silicate glass, USP Type III. 50V2 stoppers of butyl rubber and aluminium caps ("Jinan honhai glass company limited", China); polymer ampules of capacity $10 \mathrm{ml}$ of polyethylene of the Pharmalene ${ }^{\circledR}$ brand, $50 \mathrm{ml}$ bottles of low density polyethylene Riblene ${ }^{\circledR}$ FL 20 PH brand, manufactured by the Swiss company cars Bottelpack ${ }^{\circledR}$ Rommelag with the Blow-Fill-Seal way [18].

In order to assess the suitability of the selected plastic packaging material for its intended use, the compatibility of the material with the finished medicinal product should be demonstrated. The study of migration from plastic packing material and butyl rubber stoppers was not conducted based on the data obtained earlier in

the study of extraction from these materials. The maximum amount of detached individual substance is at levels for which toxicological safety has been demonstrated, as these packaging materials are registered in Ukraine and are authorized to use sterile veterinary or medicinal products for packaging.

The dependence of the indexes of the quality of the veterinary medicine "Argocid" when stored in different types of primary packaging was studied over 2 years at a temperature $(25 \pm 2){ }^{0} \mathrm{C}$ and relative humidity $(60 \pm 5) \%$ in climatic cameras.

Stability studies were carried out according to the indicators specified in the QCM specification: description, transparency, degree of colour, $\mathrm{pH}$ of the solution, quantitative content of argon ions, arginine and dexpanthenol, container volume, mechanical inclusions and sterility.

The quantitative content of silver ions in the preparation was determined thiocyanometrically. Quantitative determination of dexpanthenol was carried out by liquid chromatography. Determination of the degree of transparency of the drug "Argocid" was carried out in accordance with the procedure of SPhU p.2.2.1. The solution should be clear in compare to water for injection.

Determination of the degree of coloration of fluids in a row of brown - yellow - red was made visually by comparison with the relevant standards one of two methods specified in the SPhU in 2.2.2. The $\mathrm{pH}$ test was performed on a $\mathrm{pH}$ meter Mettler Toledo S20 KS. The tests were carried out in accordance with SPhU 2.2.3 [19]. in Table. 1

The results of experimental studies are presented

Table 1

Results of the study of the stability of the drug "Argocid" in the process of storage at a temperature $(25 \pm 2){ }^{0} \mathrm{C}$ in ampoules of light protection glass IP-10V KI-sz 1 hydrolytic class Fiolax

\begin{tabular}{|c|c|c|c|c|c|c|}
\hline \multirow{2}{*}{ Quality indexes } & \multirow{2}{*}{$\begin{array}{c}\text { Initial } \\
\text { data }\end{array}$} & \multicolumn{5}{|c|}{ Duration of storage, months. } \\
\hline & & \begin{tabular}{l|l|}
6 & \\
\end{tabular} & 9 & \begin{tabular}{|l|l|}
12 & \\
\end{tabular} & 18 & 24 \\
\hline Description & \multicolumn{6}{|c|}{ Transparent liquid of light yellow colour } \\
\hline Transparency & \multicolumn{6}{|c|}{ Transparent } \\
\hline Degree of colour & \multicolumn{6}{|c|}{ Maintains a comparison with the $\mathrm{Y}_{5}$ standard } \\
\hline Mechanical inclusions & \multicolumn{6}{|c|}{$\begin{array}{l}\text { Particles of size } \geq 10 \text { microns should be no more than } 6000 \text { per ampoule } \\
\text { Particles of size } \geq 25 \text { microns should not be more than } 600 \text { per ampoule } \\
\text { Corresponds }\end{array}$} \\
\hline Sterility & \multicolumn{6}{|c|}{ Corresponds } \\
\hline $\mathrm{pH}$ of the solution $(6.0-7.0)$ & $6.43 \pm 0.01$ & $6.42 \pm 0.03$ & $6.45 \pm 0.01$ & $6.44 \pm 0.02$ & $6.45 \pm 0.01$ & $6.46 \pm 0.02$ \\
\hline $\begin{array}{l}\text { Quantitative content of } \\
\text { argentum ions (not less } \\
\text { than } 0.45 \mathrm{mg} / \mathrm{ml} \text { ) }\end{array}$ & $0.49 \pm 0.01$ & $0.48 \pm 0.02$ & $0.48 \pm 0.01$ & $0.47 \pm 0.01$ & $0.47 \pm 0.01$ & $0.46 \pm 0.01$ \\
\hline $\begin{array}{l}\text { Quantitative content of } \\
\text { dexpanthenol, } \mathrm{mg} / \mathrm{ml} \\
(23.7-26.3)\end{array}$ & $24.95 \pm 0.01$ & $24.94 \pm 0.02$ & $24.90 \pm 0.02$ & $24.90 \pm 0.01$ & $24.90 \pm 0.2$ & $24.89 \pm 0.01$ \\
\hline $\begin{array}{l}\text { Quantitative content of } \\
\text { arginine, } \mathrm{mg} / \mathrm{ml} \\
(24.7-27.3)\end{array}$ & $25.35 \pm 0.01$ & $25.34 \pm 0 . y 02$ & $25.35 \pm 0.01$ & $25.30 \pm 0.01$ & $25.30 \pm 0.02$ & $25.30 \pm 0.01$ \\
\hline $\begin{array}{l}\text { Volume of container } \\
\text { content (not less than } \\
10.0 \mathrm{ml} \text { ) }\end{array}$ & $10.05 \pm 0.13$ & $10.05 \pm 0.14$ & $10.05 \pm 0.12$ & $10.05 \pm 0.16$ & $10.05 \pm 0.12$ & $10.05 \pm 0.12$ \\
\hline Container tightness & \multicolumn{6}{|l|}{$\begin{array}{l}\text { Must be tight } \\
\text { Corresponds }\end{array}$} \\
\hline
\end{tabular}

Note: $P \pm 95 \%, n=5$ 
As the research has shown, selected glass containers made of light-protective glass of the mark IP-10B KIsz 1 of the hydrolytic class Fiolax do not cause changes in the quality indices of the veterinary medicine, regulated in the specification of the quality control methods developed by us, for the medicinal product "Argocid", solution for intramammary administration and allow the drug to remain stable for 2 years.

When studying the stability of the drug "Argocid" in the process of storage at a temperature $(25 \pm 2){ }^{0} \mathrm{C}$ for 2 years in bottles of glass light protection capacity of $50 \mathrm{ml}$ obtained similar results as shown in Table 1.

Strengthening the regulatory criteria for the safety of veterinary drugs, focused on Blow-Fill-Seal technology as the best solution for sterile aseptic production. Blow-Fill-Seal technology is a modern process of aseptic packaging of sterile solutions. This technology provides a high level of product sterility, eliminates the need for human intervention in the production of medicines, increases production as a result of uninterrupted work of equipment, and has recently been gaining more recognition in the market of sterile veterinary medicines, replacing traditional glass bottles.

In order to determine the suitability of the primary packaging for the "Argocid" veterinary medicine, we also investigated plastic containers of $10 \mathrm{ml}$ of Pharmalene ${ }^{\circledR}$ and $50 \mathrm{ml}$ bottles of low density polyethylene of the Riblene ${ }^{\circledR}$ FL 20 PH brand. Data of experimental studies are presented in Table. 2

Table 2

Results of the study of the stability of the drug "Argocid" in the process of storage at a temperature $(25 \pm 2){ }^{0} \mathrm{C}$ in ampoules of polyethylene mark Pharmalene ${ }^{\circledR}$

\begin{tabular}{|c|c|c|c|c|c|c|}
\hline \multirow{2}{*}{ Quality indexes } & \multirow{2}{*}{ Initial data } & \multicolumn{5}{|c|}{ Duration of storage, months. } \\
\hline & & 6 & 9 & 12 & 18 & 24 \\
\hline Description & \multicolumn{6}{|c|}{ Transparent liquid of light yellow colour } \\
\hline Transparency & \multicolumn{6}{|c|}{ Transparent } \\
\hline Degree of colour & \multicolumn{6}{|c|}{ Maintains a comparison with the $\mathrm{Y}_{5}$ standard } \\
\hline Mechanical inclusions & \multicolumn{6}{|c|}{$\begin{array}{l}\text { Particles of size } \geq 10 \text { microns should be no more than } 6000 \text { per ampoule } \\
\text { Particles of size } \geq 25 \text { microns should not be more than } 600 \text { per ampoule } \\
\text { Corresponds }\end{array}$} \\
\hline Sterility & \multicolumn{6}{|c|}{ Corresponds } \\
\hline $\begin{array}{l}\mathrm{pH} \text { of the solution } \\
(6.0-7.0)\end{array}$ & $6.43 \pm 0.01$ & $6.42 \pm 0.02$ & $6.43 \pm 0.01$ & $6.42 \pm 0.02$ & $6.43 \pm 0.01$ & $6.41 \pm 0.03$ \\
\hline $\begin{array}{l}\text { Quantitative content of } \\
\text { argentum ions (not } \\
\text { less than } 0.45 \mathrm{mg} / \mathrm{ml} \text { ) }\end{array}$ & $0.49 \pm 0.01$ & $0.51 \pm 0.03$ & $0.53 \pm 0.03$ & $0.54 \pm 0.02$ & $0.56 \pm 0.03$ & $0.57 \pm 0.02$ \\
\hline $\begin{array}{l}\text { Quantitative content of } \\
\text { dexpanthenol, } \\
\mathrm{mg} / \mathrm{ml}(23.7-26.3)\end{array}$ & $24.95 \pm 0.01$ & $25.01 \pm 0.05$ & $25.06 \pm 0.02$ & $25.11 \pm 0.02$ & $25.16 \pm 0.02$ & $25.23 \pm 0.02$ \\
\hline $\begin{array}{l}\text { Quantitative content of } \\
\text { arginine, } \\
\text { mg/ml }(24.7-27.3)\end{array}$ & $25.35 \pm 0.01$ & $25.37 \pm 0.01$ & $25.39 \pm 0.02$ & $25.42 \pm 0.04$ & $25.46 \pm 0.02$ & $25.52 \pm 0.01$ \\
\hline $\begin{array}{l}\text { Volume of container } \\
\text { content } \\
\text { (not less than } 10.0 \mathrm{ml} \text { ) }\end{array}$ & $10.05 \pm 0.13$ & $10.03 \pm 0.01$ & $10.01 \pm 0.01$ & $10.00 \pm 0.01$ & $10.00 \pm 0.01$ & $9.90 \pm 0.12$ \\
\hline Container tightness & \multicolumn{6}{|l|}{$\begin{array}{l}\text { Must be tight } \\
\text { Corresponds }\end{array}$} \\
\hline
\end{tabular}

When storing samples of the veterinary drug "Argocid" in plastic containers (ampoules of $10 \mathrm{ml}$ ), a tendency to reduce the volume of packaging contents was established. As a result, a slight increase in the concentration of the components of the drug in the solution was noted, which is confirmed by the determination of the quantitative content of silver, arginine and dexpanthenol. But these changes were within the regulated indicators of the QCM specification.

Reducing the contents of the packaging was determined gravimetrically by weighing the samples under test every 0.5 years. Data on the study of reducing the contents of the packaging during storage (temperature $(25 \pm 2){ }^{0} \mathrm{C}$, relative humidity $(60 \pm 5) \%$ are presented in Fig. 1.

From Fig. 1 it is evident that in the process of storage of medicinal product "Argocid" in plastic con- tainers made of polyalene Pharmalene ${ }^{\circledR}$ brand with a capacity of $10 \mathrm{ml}$ for 2 years there is a decrease in volume to $1,5 \%$. However, the evaporation rate of the solvent is too small for the concentration of active substances to exceed the acceptable values.

For the purpose of determining the suitability of the primary packaging, similar studies of the drug "Argocid" in bottles of $50 \mathrm{ml}$ capacity of low density polyethylene of the Riblene ${ }^{\circledR}$ FL 20 PH brand were performed. Similar data are obtained on the stability of the drug "Argocid", which are listed in Table. 2

The conducted studies showed that all investigated types of containers are suitable for use as an initial packaging for the veterinary drug "Argocid", a solution for intramammary administration on the basis of silver citrate, since they allow the drug to remain stable for 2 years. 


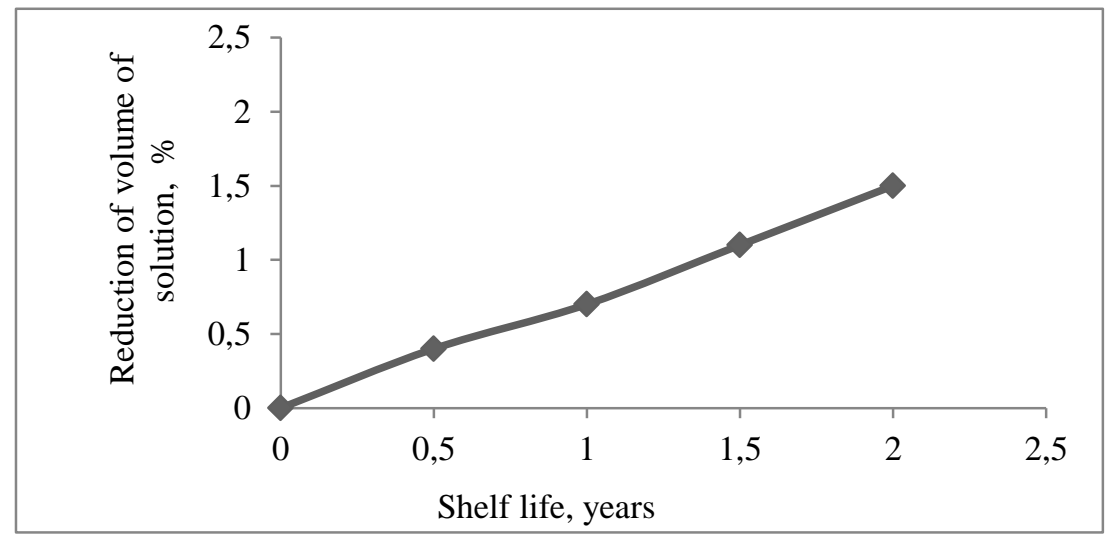

Fig. 1. Dynamics of the process of reducing the content of a container of polyethylene Pharmalene ${ }^{\circledR}$ brand when stored.

\section{Conclusions from the conducted research and prospects for further development of this field}

1. The study of the influence of primary packaging on the quality of the solution on the basis of silver citrate under the conventional name "Argocid", namely: ampoules of $10 \mathrm{ml}$ capacity and vials with a capacity of $50 \mathrm{ml}$ made of light-protection glass; plastic containers (ampoules) in a capacity of $10 \mathrm{ml}$ and $50 \mathrm{ml}$ vials to determine the shelf life of the veterinary drug in the appropriate package.

2. It was investigated that $10 \mathrm{ml}$ plastic containers of Pharmalene ${ }^{\circledR}$ grade polyethylene, $50 \mathrm{ml}$ bottles of Riblene ${ }^{\circledR}$ FL 20 PH low density polyethylene, do not cause changes in the quality of veterinary solutions that are regulated in the specification and allow the product to remain stable during storage 2 years.

3 . In the process of storing a solution based on silver citrate in plastic containers of the Pharmalene ${ }^{\circledR}$ brand of $10 \mathrm{ml}$ capacity occurred a volume reduction of up to $1.5 \%$ over a period of 2 years. However, the evaporation rate of the solvent is too small for the concentration of active substances to exceed the acceptable values.

4. It was found that all investigated types of containers are suitable for use as an initial packaging for the veterinary drug "Argocid", a solution for intramammary administration on the basis of silver citrate, since they allow the drug to be stable for 2 years.

\section{References}

1. ISO 15378:2011. Primary packaging materials for medicinal products - Particular requirements for the application of ISO 9001:2008, with reference to Good Manufacturing Practice (GMP). International Organization for Standardization, 2011.

2. Nastanova 42-3.2:2004. Nastanovy z yakosti. Likarski zasoby. Spetsyfikatsiyi: kontrolni vyprobuvannia ta kryteriyi pryiniatnosti. Kyiv: MOZ Ukrainy, 2004. 38 p.

3. Encyclopedia of pharmaceutical technology / J. Swarbick (Ed.). 3rd ed. New York, London: Informa healthcare, 2007. $1171 \mathrm{p}$.

4. Nastanova 42-3.16:2014. Nastanovy z yakosti: Likarski zasoby. Plastykovi materialy dlia pervynnoi upakovky likarskykh zasobiv. Kyiv: MOZ Ukrainy, 2014. 22 p.

5. Gudz' N. I. Osobye trebovaniya k upakovke dlya zhidkih parenteral'nyh i glaznyh lekarstvennyh form // Tovaroznavchyi analiz tovariv obmezhenoho aptechnoho asortymentu: materialy III naukovo-praktychnoi internet-konferentsiyi z mizhnarodnoiu uchastiu. Kharkiv: Vyd-vo NFaU, 2016. P. 90-91. $3655 \mathrm{p}$.

6. European pharmacopoeia 8th ed. Strasbourg: European Directorate for the Quality of Medicines \& Health Care, 2013.

7. Tekhnolohiya likiv promyslovoho vyrobnytstva. Ch. 2: pidruchnyk / Chuieshov V. I., Hladukh Ye. V., Saiko I. V. et. al. Kharkiv: NFaU: Oryhinal, 2013. 638 p.

8. Campbell G. A., Vallejo E. Influence of the glass packing on the contamination of pharmaceutical products by aluminium. Part III: Interaction container-chemicals during the heating for sterilization // Journal of Pharmaceutical Sciences. 2015. Issue 104 (1). P. 52-62.

9. Hussong D. Sterile Products: Advances and Challenges in Formulation, Manufacturing and Regulatory Aspects - A Regulatory Review Perspective // AAPS PharmSciTech. 2010. Vol. 11, Issue 3. P. 1482-1484. doi: 10.1208/s12249-010-9503-z

10. Akala Emmanuel O. Effect of Packaging on Stability of Drugs and Drug Products. Pharmaceutical Manufacturing: Regulations and Quality. John Wiley \& Sons, 2010. doi: 10.1002/9780470571224.pse392

11. Hroncich C. Examining Blow-Fill-Seal Technology for Aseptic Processes Industry experts discuss common considerations and recent technological advancements in blow-fill-seal technology // Pharmaceutical Technology. 2016. Vol. 40, Issue 6. P. 49-51.

12. Interaction of antimicrobial preservatives with blow-fill-seal packs: correlating sorption with solubility parameters / Amin A., Dare M., Sangamwar A., Bansal A. K. // Pharmaceutical Development and Technology. 2011. Vol. 17, Issue 5. P. 614-624. doi: $10.3109 / 10837450.2011 .557733$

13. Stability of $10 \mathrm{mg} / \mathrm{mL}$ cefuroxime solution for intracameral injection in commonly used polypropylene syringes and new ready-to-use cyclic olefin copolymer sterile vials using the LC-UV stability-indicating method / Feutry F., Simon N., Genay S., Lannoy D., Barthélémy C., Décaudin B. et. al. // Drug Development and Industrial Pharmacy. 2015. Vol. 42, Issue 1. P. $166-174$. doi: $10.3109 / 03639045.2015 .1038273$ 
14. Markarian J. Blow-fill-seal Technology Advances in Aseptic Filling Applications. New advanced aseptic manufacturing technologies are available for filling liquid pharmaceuticals, including biologics // Equipment and Processing Report. 2014. URL: http://www.pharmtech.com/blow-fill-seal-technology-advances-aseptic-filling-applications

15. Simmchen J., Ventura R., Segura J. Progress in the Removal of Di-[2-Ethylhexyl]-Phthalate as Plasticizer in Blood Bags // Transfusion Medicine Reviews. 2012. Vol. 26, Issue 1. P. 27-37. doi: 10.1016/j.tmrv.2011.06.001

16. Polova Z., Almakayeva L., Nehoda T. Development of the composition of intramammary combined preparation based on silver citrate for veterinary // Ceska a Slovenska Farmacie. 2017. Issue 66 (5). P. 227-233.

17. Polova Zh. N., Almakaeva L. G. Issledovanie stabil'nosti obrazcov protivomastitnogo preparata «Argocid» // Respublikanskiy nauchnyy zhurnal «VESTNIK» Yuzhno-Kazahstanskoy gosudarstvennoy farmacevticheskoy akademii. 2017. Issue 4 (81). P. 154-159.

18. Sayt TzOV «Brovafarma». URL: http://brovafarma.com.ua/uk/news/evropejs-ki-tehnologii-virobnictva-za-gmp.html

19. Derzhavna farmakopeia Ukrainy. Vol. 1. 2-e vyd. Kharkiv: Derzhavne pidpryiemstvo «Ukrainskyi naukovyi ekspertnyi farmakopeinyi tsentr yakosti likarskykh zasobiv», 2015. $1128 \mathrm{p}$.

Дата надходження рукопису 16.01.2018

Zhanna Polova, PhD, association of professor, Department of pharmaceutical and industrial technology of medicines, O. O. Bogomolets National Medical University, T. Shevchenko blvd., 13, Kyiv, Ukraine, 01601 E-mail: zpolova@ukr.net

Lyudmyla Almakayeva, Doctor of Pharmaceutical Sciences, Professor, Head of laboratory, Laboratory of parenteral and oral liquid medicines , National University of Pharmacy, Pushkinska str., 53, Kharkiv, Ukraine, 61002

UDC 582.282.23:57.017.4:615.282:618.15-002.828

DOI: 10.15587/2519-4852.2018.124534

\section{IN VITRO SUSCEPTIBILITY STUDY OF CANDIDA SPP. ISOLATES TO NEW COMBINED POTENTIAL MEDICINAL PRODUCT FOR THE TREATMENT OF VAGINAL CANDIDIASIS}

\section{(C) I. Nizhenkovska, L. Zinchenko}

Дослідження протимікробної дї модельних зразків потенційного лікарського засобу у різних фіксованих комбінаціях та доведення специфічної антимікотичної активності модельних зразків нового, комбінованого, потениійного лікарського засобу та препарату, обраного в якості референтного «НеоПенотран $^{\circledR} \gg($ Екселтіс Хелске С.Л., Іспанія).

Метою дослідження було встановлення чутливості in vitro ізолятів Candida spp. до нового комбінованого лікарського засобу, що містить в своєму складі субстанцію з антимікотичною дією для лікування вагінального кандидозу.

Матеріали та методи. Для доведення активності та визначення чутливості використовували ізоляти Candida albicans (ATCC 10231) ma Candida albicans (клінічний ізолят) з матеріалу, урогенітальних шляхів від жінок з діагнозом кандидоз.

Вивчення протимікробної дї проводили за методом серійних розведень в триптиказо-соєвому бульйоні, щзо дозволив забезпечити рівномірний розподіл препарату в поживному середовищі при контакті з патогенними штамами, а подальший пересів на чашки Петрі на Сабуро агар - найбільш точну оцінку результатів.

Результати вивчення антимікотичної активності 7 модельних зразків, свідчать про наявність антимікотичної активності лише у 3 модельних зразках по відношенню як до еталонного штаму Candida albicans ATCC 10231, так і клінічного штаму Candida albicans.

Висновки. Отримані результати досліджень свідчать про наявність виразного антимікотичного ефекту in vitro нового потенційного комбінованого лікарського засобу відносно патогенних тест-цтамів: Candida albicans ATCC 10231, Candida albicans (клінічний ізолят), який не поступається обраному референтному препарату. Встановлено мінімільну інгібуючу кониентрацію досліджуваного препарату іп vitro відносно патогенних тест-итамів: Candida albicans ATCC 10231, Candida albicans (клінічний ізолят). Проведене дослідження різних комбінаџій та кониентрацій комбінованого препарату дозволило виключити наявність негативної взаємодії між компонентами експериментального зразку та виділити найбільш перспективний та ефективний зразок для подальших експериментальних досліджень комбінацій антимікотиків для інтравагінального застосування

Ключові слова: супозиторії, вагінальний кандидоз, антимікозна активність 